\title{
Program for Dental Health Advancement in Children „Dental Passport“"
}

\section{Program unaprjeđenja dentalnog zdravlja djece Zubna putovnica}

\author{
${ }^{1}$ Croatian Institute of Public Health \\ Hrvatski zavod za javno zdravstvo \\ 2 School of Dental Medicine, Faculty of Zagreb \\ Stomatološki fakultet Sveučilišta u Zagrebu \\ ${ }^{3}$ Ministry of Health, Republic of Croatia \\ Ministarstvo zdravstva Republike Hrvatske
}

\section{Abstract}

Objective: The need for improving oral health in the Republic of Croatia was based on health indicators and poor oral health status and resulted in the implementation of measures to improve the use of dental health care for schoolchildren through the national program called "Dental Passport", which began in the 2017/2018 school year. Purpose: The aim of this study was to present the content and results of its implementation and to analyse them with emphasis on the sustainability and inclusion of the program and its implementation in preventive activities and procedures. Material and Methods: The data were collected from the completed “Dental Passport” forms from September 2017 to August 2018. The dental examinations and diagnostic-therapeutic procedures were recorded in The Central Health Information System of Croatia. Results: In the school year $2017 / 2018,24,7296^{\text {th }}$ grade elementary school students visited a dentist. The response rate in the Republic of Croatia was $68 \%$. According to the CEZIH data, in the period from September 1 to December 31 2017, an increase in the number of first examinations and diagnostic-therapeutic procedures was observed in children aged 12 years, compared to the same period in 2015. The least reported preventive procedures in preschool children and $6^{\text {th }}$ grade students were fissure sealing and sealing restorations, while motivating and instructing children on oral hygiene were the most common reported procedures. Conclusion: Good organization of work in school medicine provides the basis for the implementation of dental programs involving schoolchildren. However, greater motivation of the dental health care provider in the implementation of preventive procedures and motivation of parents and patients for a more active involvement in the "Dental Passport" program are important determinants in further implementation and improvement of oral health in children.
Received: February 17, 2020

Accepted: May 7, 2020

Address for correspondence Ivana Pavić Šimetin Croatian Institute of Public Health ivana.pavic@hzjz.hr

Key words

Preventive Dental Program, Dental Passport, Preventive Procedures, Schoolchildren

\section{Introduction}

Oral health is an integral part of overall health and an important indicator of a population's health status. As an indicator of oral health, public health policy places special emphasis on health status during pre-school and school age and the implementation of preventive measures in the field of dental medicine (1). Dental caries is the most common oral cavity disease that affects $60-90 \%$ of schoolchildren and is a major public health problem (2). Knowledge on the occurrence and development of caries has led to a change in its treatment and made preventive, non-invasive procedures particularly important in reducing its prevalence. The best results are achieved with preventive activities to ensure good oral health. However, their purposefulness essentially depends on a structure that includes appropriate facilities.

Therefore, the deficiency of systems in preventive approach is the most common reason for unsuccessful pro-
Uvod

Oralno zdravlje neodvojiv je dio cjelokupnog zdravlja i pripada važnim pokazateljima zdravstvenog stanja populacije. Kao pokazatelj oralnoga zdravlja javnozdravstveno se posebno prati zdravstveno stanje u predškolskoj i školskoj dobi te provedba preventivnih mjera u području dentalne medicine (1). Zubni karijes najčešća je bolest usne šupljine koja zahvaća od 60 do $90 \%$ školske djece i veliki je javnozdravstveni problem (2). Spoznaja o nastanku i razvoju karijesa dovela je do promjene u njegovu liječenju te su preventivni, neinvazivni postupci osobito važni u smanjenju njegove prevalencije. Preventivnim aktivnostima postižu se najbolji rezultati kako bi se osiguralo dobro oralno zdravlje, ali njihova svrhovitost presudno ovisi o strukturi koja se upotpunjuje odgovarajućim sadržajima. Stoga je nedostatak sustava u preventivnom pristupu upravo najčešći razlog za neuspješne programe ili programe s nedovoljno mjerljivim učincima. U Hrvatskoj 
grams, or programs with insufficiently measurable effects. In 1991, the reform of the health care system in Croatia resulted in the loss of systematic preventive and curative dental health care for children provided by pedodontics, which resulted in a decline in the quality of dental medical care in the pediatric population and high DMF index values (4.18 in 12-year-olds, 4.14 in 6-year-olds) (3). Excessive workload in regular daily routine and provision of dental health care at the elementary level, considering specific needs of the pediatric population, did not contribute to building a sustainable prevention system through organized preventive examination (4). Good practice in European countries such as Denmark has shown that a targeted proactive approach for providing and organizing preventive care within public health dental care has had significant results in improving the oral health of the Danish population. The average DMFT index in 12-year-olds decreased by $78 \%$, from 4.5 to 0.98 , in the period from 1974 to 2000. Establishing local clinical facilities to provide free and affordable dental health care to children and adolescents, with health education and preventive activities from infants to 18-year-olds, through organized written invitations to parents and response monitoring/follow up are a good example of a successful dental program $5,6)$. The systematic dental health care in other Scandinavian countries has given low DMF figures for 12-years-olds in Sweden (0.8) and Norway (1.7). The need to plan and implement a preventive dental program in Croatia with the purpose to improve the use of dental health care for children started with the pilot project called the "Dental Passport" in the school year 2016/2017 and the project became the national program from the school year 2017/ 2018. All children aged six and 12 are referred by a school doctor to a dentist for preventive examination. The program is designed and implemented, based on the Plan and Program of Health Care Measures from Compulsory Health Insurance (Official Gazette No. 126/2009) defining specific health promotion and disease prevention measures characteristic of certain groups; pregnant women, infants and children under three years of age, preschool children (from the age three to school), school children, young people under 18 years, and adults and people over the age of 65 . They include the following preventive activities: regular check-ups, health education, tooth brushing with fluoride preparations, records of mandatory epidemiological data as defined by the World Health Organization, with the emphasis on systematic preventive dental care for children and young people (7). The aim of the Dental Passport program is to organize comprehensive preventive dental examination (dental status, preventive procedures, treatment and follow-up) for all children aged six and 12, with a response rate of $100 \%$ at age six and about $60-70 \%$ at age 12. Its purpose is reducing the DMFT index, increasing the use of fluoridation and remineralization preparations and improving oral hygiene habits in children. The aim of this study is to present the content and results of the implementation of the "Dental Passport" program and to analyse them with the focus on the sustainability and coverage of the program and its implementation in preventive activities and procedures. je 1991. godine reformiran zdravstveni sustav te se pritom dogodio gubitak sustavne preventivne i kurativne dentalne zdravstvene zaštite djece koju su do tada pružali specijalisti dječje i preventivne dentalne medicine što je rezultiralo padom kvalitete dentalno-medicinske skrbi dječje populacije i visokim KEP indeksom (4,18 kod 12-godišnjaka, 4,14 kod 6-godišnjaka) (3). Prevelika opterećenost u svakodnevnom radu i pružanje dentalne zdravstvene zaštite na primarnoj razini s obzirom na specifične potrebe dječje populacije, nisu pridonijeli izgradnji održivog sustava prevencije putem organiziranih preventivnih pregleda (4). Primjer dobre prakse europskih zemalja, poput Danske, pokazao je kako je ciljani proaktivni pristup u pružanju i organizaciji preventivne skrbi unutar javnozdravstvene dentalne zaštite imao značajne rezultate u poboljšanju oralnoga zdravlja tamošnjeg stanovništva. Od 1974. do 2000. godine prosječni KEP indeks kod dvanaestogodišnjaka smanjio se za $78 \%$ - s 4,5 na 0,98. Osnivanje lokalnih kliničkih ustanova kako bi se djeci i adolescentima pružila besplatna i dostupna dentalna zdravstvena zaštita, uz zdravstvenu edukaciju i prevenciju od novorođenčeta do 18 -godišnjaka te organizirano pozivanje roditelja putem pisma i praćenje odaziva dobar su primjer uspješnog dentalnog programa $(5,6)$. Sustavna skrb o oralnom zdravlju u drugim skandinavskim zemljama rezultirala je niskim vrijednostima KEP indeksa kod 12-godišnjaka (Švedska 0,8, Norveška 1,7). Potreba za planiranjem i provedbom preventivnog dentalnog programa u Hrvatskoj radi poboljšanja primjene dentalne zdravstvene zaštite djece počelo je $s$ pilotprojektom pod nazivom Zubna putovnica u školskoj godini 2016./2017., a koji je od školske godine 2017./2018. postao nacionalni program. Školski liječnik upućuje na preventivni pregled doktoru dentalne medicine svu djecu u dobi od $6 \mathrm{i}$ 12 godina. Program je osmišljen i implementiran na temelju Plana i programa mjera zdravstvene zaštite iz obveznog zdravstvenog osiguranja (NN126/2009) kojim su propisane specifične mjere promicanja zdravlja i prevencije bolesti karakterističnih za pojedine skupine, trudnice, dojenčad i djecu do 3 godine, predškolsku djecu (od 3. godine do polaska u školu), školsku djecu, mladež do 18 godina zatim odrasle i starije od 65 godina te uključuju sljedeće preventivne aktivnosti: redovite preglede, zdravstveni odgoj, četkanje zuba preparatima fluora, evidenciju obveznih epidemioloških podataka prema naputku Svjetske zdravstvene organizacije, s naglaskom na sustavnu preventivnu dentalnu zaštitu djece i mladeži (7). Cilj programa Zubna putovnica je organizirati sveobuhvatan preventivni stomatološki pregled (dentalni status, preventivni postupci, liječenje i praćenje) za svu djecu u dobi od 6 do 12 godina, sa stopom odgovora od $100 \%$ u dobi od 6 godina i od 60 do 70 u dobi od 12 godina, u svrhu smanjenja KEP indeksa, povećanja upotrebe preparata za fluoridaciju i remineralizaciju te poboljšanja oralno-higijenskih navika kod djece. Svrha ovog rada je predstaviti sadržaj i rezultate provedbe programa te ih analizirati s naglaskom na održivost i obuhvatnost programa te provedbu preventivnih aktivnosti, odnosno postupaka. 


\section{Material and Methods}

The data were collected from the completed "Dental Passports" forms between September 2017 and August 2018 (Figure 1). The $6^{\text {th }}$ grade students (12 years old) and preschoolers enrolling in the $1^{\text {st }}$ grade of elementary school (6 years old) had received the forms directly from the school medicine doctor or at school. During systematic examination when enrolling in the first grade of elementary school, the "Dental Passport" form is a part of the compulsory medical documentation collected by the school doctor. From $6^{\text {th }}$ grade students, the form was collected during the following regular activities: Hepatitis B vaccination, spinal examination and control of height and weight (growth and development monitoring). After dental examination, the child / parent / guardian returned the completed form to the school medicine doctor. The collected forms were sent to the Croatian Institute of Public Health, where data were entered through a system for centralized information collection based on an open source project - Lime Survey (8).

In the school year 2016/2017, data were entered for all examined $6^{\text {th }}$ grade students in Splitsko-Dalmatinska and Primorsko-Goranska County from those who had returned the completed forms. In the school year 2017/2018, samples were entered for $6^{\text {th }}$ grade students and pre-schoolers enrolling in the $1^{\text {st }}$ grade of elementary school from each county of Croatia. The data included the following: demographic data (age and sex), dental status (healthy tooth, caries, tooth extracted due to caries, filled tooth), preventive procedures, treatment and follow-up visits. The dental examinations and diagnostic-therapeutic procedures were recorded in the Central Health Information System of Croatia during clinical examinations carried out by dental practitioners who were contractors of the Croatian Health Insurance Fund.

\section{Results}

In the school year 2016/2017, out of the 6,994 planned $6^{\text {th }}$ grade students, $51.6 \%$ were examined in the SplitskoDalmatinska and Primorsko-Goranska county. According to the CEZIH data, between September 1 and December 31,2015 , there was a total of 5,761 dental inspections of 12 -year-old children. For the same period in 2016, the number of dental consultations was 9,648 and 11,911 , respectively, in 2017. The number of preventive procedures (topical fluoridation, motivation and demonstration of tooth brushing, fissure sealing per tooth, sealing restorations) in twelveyear-olds in 2016 increased by $118 \%$ compared to the same period in 2015, and by $19 \%$ in 2017 compared to 2016 (Figure 2). In the school year 2017/2018 (20 counties and City of Zagreb), out of the total number of $6^{\text {th }}$ grade students, $98.8 \%$ of them received the form directly from the school medicine doctor or at school in September 2017. In the period from September 2017 to June 2018, out of 3,184 students, 24,729 have visited dentists, with the response rate of $68 \%$ for the Republic of Croatia. The analysis showed that the numbers of $6^{\text {th }}$-grade students in that period ranged from almost complete examinations by dentists (Krapinsko-Za-

\section{Materijali i postupci}

Podatci su prikupljeni iz ispunjenih obrazaca Zubna putovnica u razdoblju od rujna 2016. do lipnja 2018. godine (slika 1.). Obrasce su učenici 6. razreda osnovne škole (dob: 12 godina) i pri upisu u 1. razred osnovne škole (dob: 6 godina) dobili od doktora školske medicine izravno ili od škole. Tijekom sistematskog pregleda pri upisu u prvi razred osnovne škole obrazac Zubna putovnica je dio obvezne medicinske dokumentacije koju je prikupljao doktor školske medicine. Kod učenika 6. razreda obrazac se prikupljao na sljedećim redovitim aktivnostima: cijepljenju protiv hepatitisa B te pregledu kralježnice, visine i mase (praćenje rasta i razvoja). Nakon obavljenog pregleda kod doktora dentalne medicine, ispunjeni obrazac je dijete/roditelj/skrbnik vratio doktoru školske medicine. Prikupljeni obrasci dostavljeni su Hrvatskom zavodu za javno zdravstvo gdje su se podaci unosili u sustav za centralizirano prikupljanje informacija utemeljen na projektu otvorenog koda - Lime Survey (8). U školskoj godini 2016./2017., unosili su se podatci za sve pregledane učenike 6. razreda u Splitsko-dalmatinskoj i Primorsko-goranskoj županiji koji su vratili ispunjeni obrazac, a u 2017./2018. unosili su se uzorci iz svake županije Republike Hrvatske za učenike 6 . razreda i za upis u 1. razred osnovne škole. Podatci su uključivali sljedeće: demografske podatke (dob i spol), dentalni status (zdravi zub, karijes, zub izvađen zbog karijesa, zub $s$ ispunom), preventivne postupke te podatke o liječenju i idućem, odnosno kontrolnom posjetu. Pregledi i dijagnostičko-terapijski postupci (DTP) također su se bilježili u sklopu Centralnoga zdravstvenog informacijskog sustava (CEZIH) tijekom posjeta i kliničkog pregleda djece u ordinacijama dentalne medicine koje su imale sklopljene ugovore s Hrvatskim zavodom za zdravstveno osiguranje (ugovorni subjekti HZZO-a). Rezultati su obrađeni u programu Microsoft Access 2.0. te su prikazani tablično i grafički.

\section{Rezultati}

U školskoj godini 2016./2017. u Splitsko-dalmatinskoj i Primorsko-goranskoj županiji, od planiranih 6.994 učenika 6. razreda, njih 51,6 \% bilo je obuhvaćeno pregledom. Prema podatcima CEZIH-a, u razdoblju od 1. rujna do 31. prosinca 2015. godine zabilježen je ukupno 5.761 posjet djece od 12 godina. $\mathrm{Za}$ isto razdoblje 2016 . godine broj posjeta djece u dobi od 12 godina bio je 9.648 i 11.911 u 2017. godini. Ukupan broj preventivnih postupaka (topikalna fluoridacija, motivacija i demonstracija četkanja zuba, pečaćenje fisura po zubu, preventivni ispun) kod dvanaestogodišnjaka u 2016. godini porastao je za $118 \%$ u odnosu prema istom razdoblju 2015. godine, a u 2017. za $19 \%$ u usporedbi s 2016. (slika 2.). U školskoj godini 2017./2018. (20 županija i Grad Zagreb) od ukupnog broja učenika 6. razreda 98,8 \% dobilo je obrazac izravno od doktora školske medicine ili u školi u rujnu 2017. godine. U razdoblju od rujna 2017. do lipnja 2018. godine, od planiranih 39.184 učenika, doktora dentalne medicine posjetilo je 24.729 učenika, s odazivom od $68 \%$ za cijelu Republiku Hrvatsku. Analiza je pokazala da je u tom razdoblju broj pregledanih učenika 6. razreda bio gotovo potpun u Krapinsko-zagorskoj žu- 
gorska 98.7\%) to marginal implementation (The City of Zagreb $25.1 \%$ )(Figure 3). In the sample of $6,8026^{\text {th }}$ grade students, the most commonly observed preventive procedures were motivation of children for oral hygiene demonstration of mouth cleaning topical fluoridation - liquid or gel, while fissure sealing per teeth and sealing restorations were the least reported procedures (Figure 4). During the examination, treatment was not required in $51.92 \%$ of children, while the start of a treatment was planned for the next visit in $26.48 \%$ of children, and in $12.19 \%$ treatment was started at the same visit, with $9.41 \%$ of children whose treatment was started and completed on the same visit. Motivation of children for oral hygiene, demonstrations of mouth cleaning and topical fluoridation were the most performed preventive procedures found in Viroviticko-Podravska and Sibensko-Kninska counties, while the number of fissure sealing per tooth was highest in Dubrovnicko-Neretvanska county, Pozesko-Slavonska county and in the City of Zagreb (Figure 5). According to the CEZIH data, in the period from September 1 to December 31, 2017, an increase in the number of first examinations (by 174\%) and diagnostic and therapeutic procedures was observed in children aged 12 compared to the same period in 2015 (Figure 6). During examinations (spring of 2018) which included the generation of preschool children $(42,432)$ enrolling in the first grade of elementary school for the 2018/2019 school year, a sample of 4,410 children revealed that $31.15 \%$ of children did not need treatment, while $39.64 \%$ needed treatment that was planned for the next visit or started and completed during the same visit. The least performed preventive procedures for preschool children were fissure sealing and sealing restorations, followed by fluoride prophylaxis, while demonstrating mouth cleaning and motivating children for oral hygiene were the most commonly reported procedures (Figure 7). No gender differences were found in therapy and treatment plan.

\section{Discussion}

In 1995, the World Health Organization adopted the Global School Health Initiative to promote health care through schools, which included oral health care (9). Globally, about $80 \%$ of children attend school. Hence, schools represent a suitable environment for access to almost all population groups of children and the opportunity to play a role in national development and efforts to improve health and education among children and adolescents (10). Within the public health system of the Republic of Croatia, school medicine implements preventive, specific and health education measures, as defined in the Program for Preventive and Educational Measures for health protection of schoolchildren, which is a part of the plan and the program of health care measures covered by compulsory health insurance. (7). Considering poor oral health status in children and insufficient organized dental examinations in the Republic of Croatia, school medicine became an important specialty and link in the implementation of oral health care measures through schools, fostering parental/ guardian responsibilities for regular screening and preventive procedures. The increase in the paniji (98,7\%), a najmanje je zabilježenih pregleda bilo u Gradu Zagrebu (25,1 \%) (slika 3.). Na uzorku od 6.802 učenika 6. razreda najčešći preventivni postupci bili su motiviranje djece na higijenu usta, demonstracija čišćenja usta, topikalna fluoridacija - tekućina ili gel, a pečaćenje fisure po zubu i pečatni ispun bili su najrjeđi postupci (slika 4.). Tijekom pregleda ustanovljeno je da liječenje nije bilo potrebno za 51,92 \% djece, početak liječenja planirao se kod sljedećeg posjeta za $26,48 \%$ djece, za $12,19 \%$ liječenje je počelo tijekom prvog posjeta, a za 9,41\% djece liječenje je počelo i završeno u istom posjetu. U Virovitičko-podravskoj i Šibensko-kninskoj županiji bilo je najviše preventivnih postupaka motivacije djece za higijenu usta, demonstraciju čišcenja usta i topikalnu fluoridacije, a broj pečaćenja fisura po zubu bio je najveći u Dubrovačko-neretvanskoj i Požeško-slavonskoj županiji te u Gradu Zagrebu (slika 5.). Prema podatcima CEZIH-a, u razdoblju od 1. rujna do 31. prosinca 2017. godine kod djece u dobi od 12 godina $(\mathrm{RH})$ zabilježeno je povećanje broja prvih pregleda (za $174 \%$ ) i dijagnostičko-terapijskih postupaka u odnosu prema istom razdoblju 2015. (slika 6.). Na pregledima (proljeće 2018. godine) pri upisu u prvi razred osnovne škole za školsku godinu 2018./2019., kojim je obuhvaćena generacija predškolske djece (42.432), na uzorku od 4.410 djece ustanovljeno je da kod 31,15\% nije potreban terapijski postupak, a kod 39,64\% bilo je potrebno liječenje koje se planiralo tijekom idućeg posjeta ili je počelo i završeno u istom posjetu. Najmanje zastupljeni preventivni postupci kod predškolske djece bili su pečaćenje fisure po zubu i pečatni ispun, zatim profilaksa s fluorom, a demonstracija čišćenja usta i motiviranje za higijenu usta bili su najčešći (slika 7.). Razlike u spolu nisu zabilježene pri postupku i planu liječenja.

\section{Rasprava}

Svjetska zdravstvena organizacija je 1995. godine prihvatila inicijativu WHOs Global School Health Initiative kako bi promicala zaštitu zdravlja kroz škole, a u koju je uvrštena i zaštita oralnoga zdravlja (9). Na globalnoj razini oko $80 \%$ djece pohađa školu pa su škole prikladno okružje zbog pristupa gotovo cjelokupnim populacijskim skupinama djece i mogućnosti da pomognu u nacionalnom razvoju i naporima za poboljšanje zdravlja i edukacije među djecom i adolescentima (10). U Republici Hrvatskoj, u sustavu javnoga zdravstva, školska medicina provodi preventivne, specifične i zdravstveno odgojne mjere zdravstvene zaštite školske djece koje su određene Programom mjera za djelatnost preventivno-odgojnih mjera za zdravstvenu zaštitu školske djece iz Plana i programa mjera zdravstvene zaštite iz obveznoga zdravstvenog osiguranja (NN126/2009). S obzirom na loše oralno zdravstveno stanje djece i nedovoljno organizirane stomatološke preglede u Republici Hrvatskoj, školska medicina postala je važna specijalnost i karika u provedbi mjera zaštite oralnoga zdravlja kroz škole te poticanja odgovornosti roditelja/skrbnika na redovite preglede i preventivne postupke. Po- 
number of visits and preventive procedures for twelve-yearolds in 2016 and 2017 compared to the same period in 2015 indicates the importance of implementation of the screening program through the education system that shows that regular oral health assessment is more effective than the standard dental care model (11). The aim of programs involving schoolchildren is not only to identify children with oral health problems, but also to encourage children to contact the dental health services for regular check-ups (12). Praveen et al. reported an increase in the number of examinations and procedures in children enrolled in school dental programs compared to non-school children (13). Donaldson and Kinirons reported similar results in the study conducted among children in Northern Ireland, with emphasis on school dental programs and their role in reducing health inequalities, especially in lower socioeconomic status (14). Sometimes, schools can also be the only place where children at highest risk of hard and soft tissue diseases of the oral cavity have access to oral health services, especially in developing countries due to inaccessibility and lack of dental care (15). The inclusion analysis of examination of twelve-year-olds shows a low rate, especially in the City of Zagreb, where the use of dental health care should be satisfactory given the number of contracted teams and the availability of health compared to Zadarska county and the potential poorer accessibility given the county's divergence. In the Republic of Croatia, free dental care is provided for all children until the age of 18 , which should be motivating, taking into account socioeconomic factors and the need for expensive treatment. Almost $50 \%$ of children (0-7 years old) do not excercise the right to dental health care and enrolment for school is often the reason for the first visit to the dentist (4). The high percentage of pre-school children who require dental treatment in relation to the number of healthy children indicates the need for enhanced implementation of diagnostic and therapeutic procedures, especially for a therapeutic treatment of a new permanent tooth with existing caries. It is a critical period of risk for caries, especially since permanent molars in eruption do not have functional occlusal contact, which affects the accumulation and retention of dental plaque in fissures of the occlusal surfaces of the teeth and the action of acids on immature enamel. Adolescence is the second period of risk for caries due to poor oral hygiene and carbohydraterich foods with a high cariogenic potential. The most commonly reported preventive procedures for $6^{\text {th }}$ grade pupils in the Dental Passport Program such as motivation for oral hygiene, demonstration of tooth cleaning and fluoride prophylaxis were justifiably applied in clinical practice, although at that age there is also a need for fissure sealing or sealing restoration based on individual assessments during control examination. A low number of topical fluoridations was noted in preschool children with respect to the recommended two to four times a year, as well as the number of fissure sealing, which should be the rule, not an exception with respect to the number of preschool children requiring treatment given the relatively high incidence of caries $(16,17)$. Increase in number of dentist examinations through an organized and targeted program enables monitoring of oral health indica- većanje broja posjeta i preventivnih postupaka kod dvanaestogodišnjaka u 2016. i 2017. godini u odnosu prema istom razdoblju 2015. upućuje na važnost provođenja programa kontrolnog pregleda kroz sustav školstva koji pokazuju da je redovita procjena oralnoga zdravlja učinkovitija od standardnog modela dentalne zaštite (11). Cilj programa koji obuhvaćaju školsku djecu nije samo u tomu da bi se prepoznala djeca sa zdravstvenim problemima u usnoj šupljini, nego je to ujedno put kako potaknuti djecu na redovite kontrolne preglede dolazeći u kontakt s dentalnim zdravstvenim službama (12). Praveen i suradnici navode povećanje broja pregleda i postupaka kod djece koja su uključena u školske dentalne programe u usporedbi sa školskom djecom koja nisu uključena (13). Slične rezultate ističu Donaldson i Kinirons u studiji provedenoj među djecom u Sjevernoj Irskoj, uz naglasak na ulogu školskih dentalnih programa u smanjenju zdravstvenih nejednakosti, osobito kod nižeg socijalno-ekonomskog statusa (14). Škole katkad mogu biti i jedino mjesto na kojemu će djeca s najvećim rizikom za bolesti tvrdih i mekih tkiva usne šupljine imati pristup oralno-zdravstvenim uslugama, posebno u zemljama u razvoju zbog nedostupnosti i nedostatka stomatološke skrbi (15). Analiza obuhvaćenosti dvanaestogodišnjaka pregledom pokazuje nisku vrijednost i to osobito u Gradu Zagrebu gdje bi korištenje dentalne zdravstvene zaštite trebalo biti zadovoljavajuće $s$ obzirom na broj ugovornih timova i dostupnost zdravstvene zaštite u odnosu prema Zadarskoj županiji i potencijalno slabijoj dostupnosti s obzirom na razvedenost županije. U Republici Hrvatskoj je za svu djecu do 18 godina osigurana besplatna dentalno-medicinska skrb što bi trebalo biti motivirajuće, ako se uzmu u obzir socijalno-ekonomski čimbenici te potreba za skupim liječenjem. Gotovo $50 \%$ djece u dobi od 0 do 7 godina ne ostvaruje pravo na dentalnu zdravstvenu zaštitu, te je upis u prvi razred osnovne škole vrlo često razlog za prvi posjet doktoru dentalne medicine (4). Velik postotak pregledane predškolske djece kojoj je potrebno stomatološko liječenje u odnosu prema broju zdrave djece upućuje na potrebu za pojačanom provedbom dijagnostičko-terapijskih postupaka, osobito za sanacijom mladoga trajnog zuba s karijesom. To se razdoblje smatra rizičnim za nastanak karijesa, zato što trajni kutnjaci u erupciji nemaju funkcionalni okluzalni kontakt, što utječe na nakupljanje i zadržavanje zubnog plaka u fisurama okluzalnih površina zuba i djelovanje kiselina na nezrelu caklinu. Vrijeme adolescencije je drugo razdoblje rizično za nastanak karijesa zbog lošije higijene usne šupljine i unosa hrane bogate ugljikohidratima te visokog kariogenog potencijala. Najčešći zabilježeni preventivni postupci kod djece 6. razreda u programu Zubna putovnica (motivacija za higijenu usta, demonstracija čiśćenja usta i profilaksa s fluorom) opravdano su primijenjeni u kliničkoj praksi, iako u toj dobi postoji potreba i za pečaćenjem fisura ili izradom pečatnog ispuna na temelju individualne procjene tijekom kontrolnih pregleda. Kod predškolske djece uočen je mali broj topikalnih fluoridacija s obzirom na preporučenih dva do četiri puta na godinu, te broj pečaćenja fisura što bi trebao biti pravilo, a ne iznimka s obzirom na broj predškolske djece kojoj je potrebno liječenje zbog razmjerno visoke pojavnosti karijesa $(16,17)$. Povećanje broja pregleda kod doktora dentalne me- 


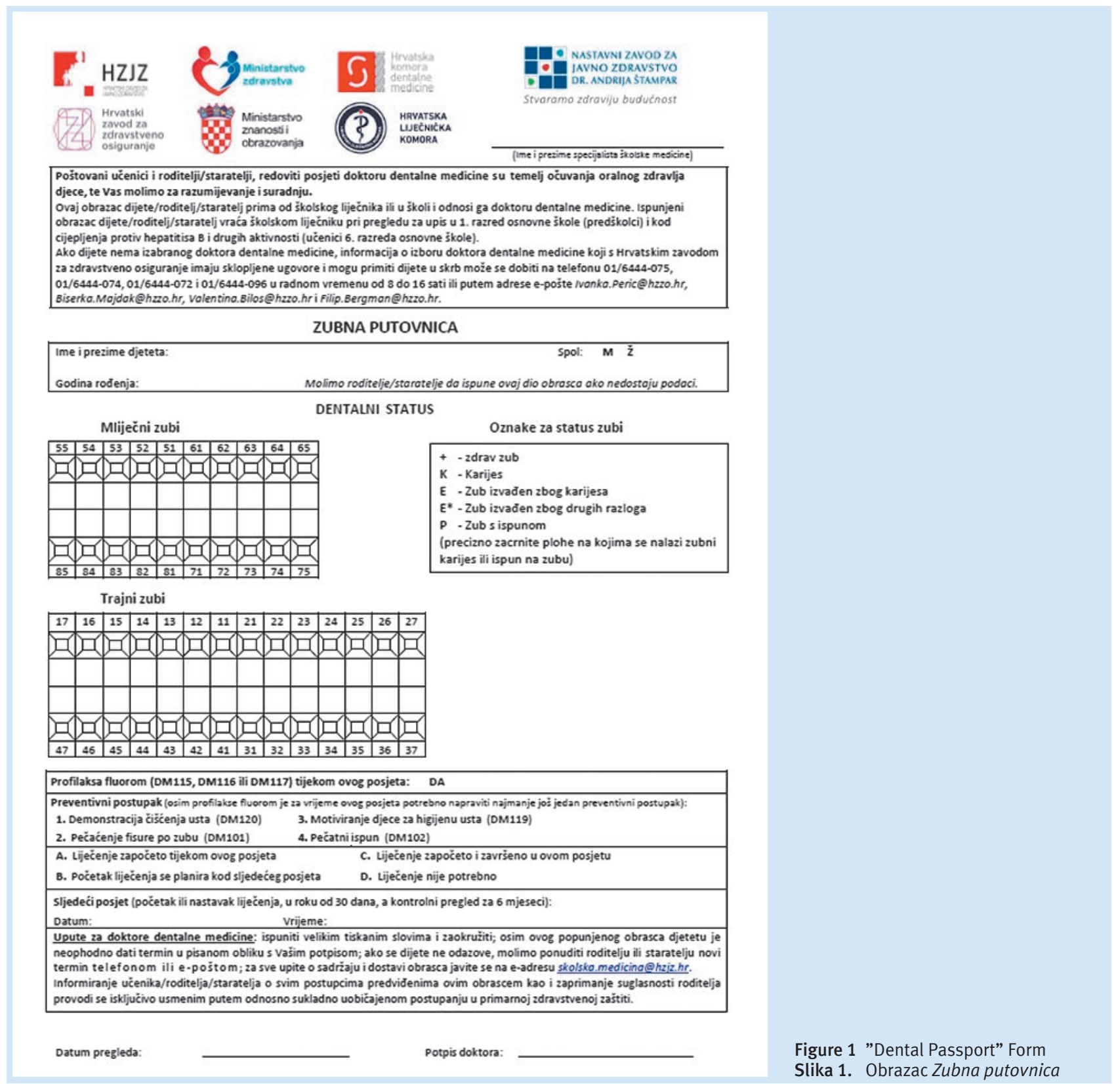

tors and application of various preventive procedures such as motivation and patient education on oral hygiene, professional mechanical tooth cleaning, the use of preparations for chemical prophylaxis and plaque control, topical fluoridation and fissure sealing and other non-invasive procedures. These procedures are recommended in childhood because they defer the development and progression of dental concern and anxiety, and show effectiveness in reducing caries.

There are studies assessing the most effective and unbiased public health intervention for caries prevention. They place emphasis on the basic principle of prevention, which states that the most efficient intervention occurs when the risk of a disease is the highest. Hausen et al. reported reduced incidence of caries in children with active caries in their study conducted among Finnish children, when a number of preventive measures had been implemented (18). Considering the need to implement preventive measures in order to im- dicine putem organiziranog i ciljanog programa omogućuje praćenje pokazatelja oralnoga zdravlja i primjenu različitih preventivnih postupaka kao što su motivacija i edukacija pacijenata o oralnoj higijeni, profesionalno mehaničko čišćenje zuba, primjena sredstava za kemijsku profilaksu i kontrolu plaka, topikalna fluoridacija i pečaćenje fisura te ostali neinvazivni postupci. Navedeni postupci mogu se preporučiti u dječjoj dobi zato što ne potiču razvoj i progresiju dentalnoga straha i anksioznosti, a učinkovito smanjuju karijes. Postoje studije u kojima autori procjenjuju koja je javnozdravstvena intervencija najučinkovitija i nepristrana u prevenciji karijesa, pri čemu je potrebno uzeti u obzir osnovno načelo prevencije, da će najučinkovitija intervencija biti kada je rizik od nastanka bolesti najveći. Hausen i suradnici u svojoj studiji koja je provedena među finskom djecom navode smanjenje incidencije karijesa kod djece s aktivnim karijesom, ali uz niz provedenih preventivnih mjera (18). S obzirom na potre- 

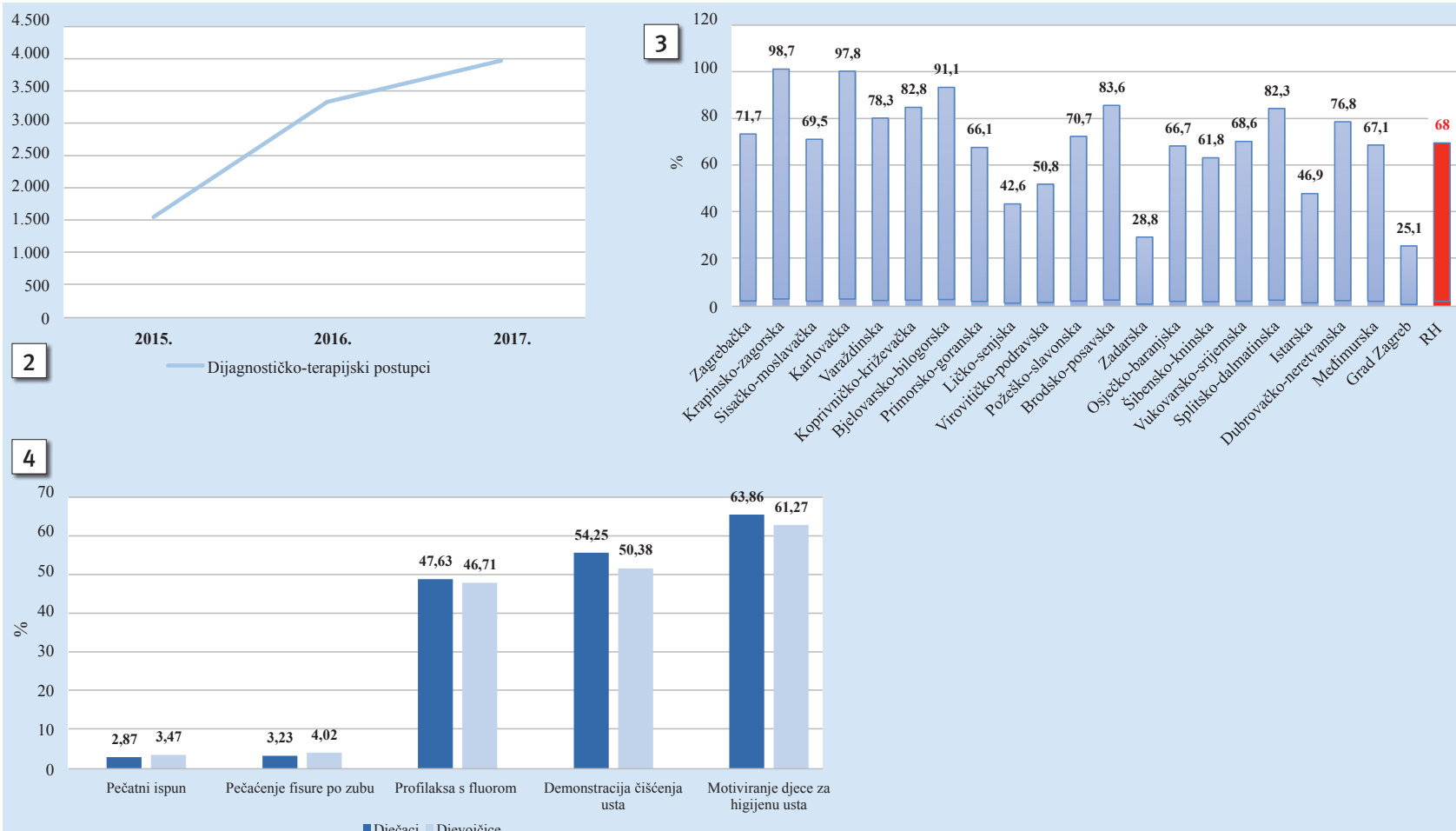

- Dječaci Djevojěice
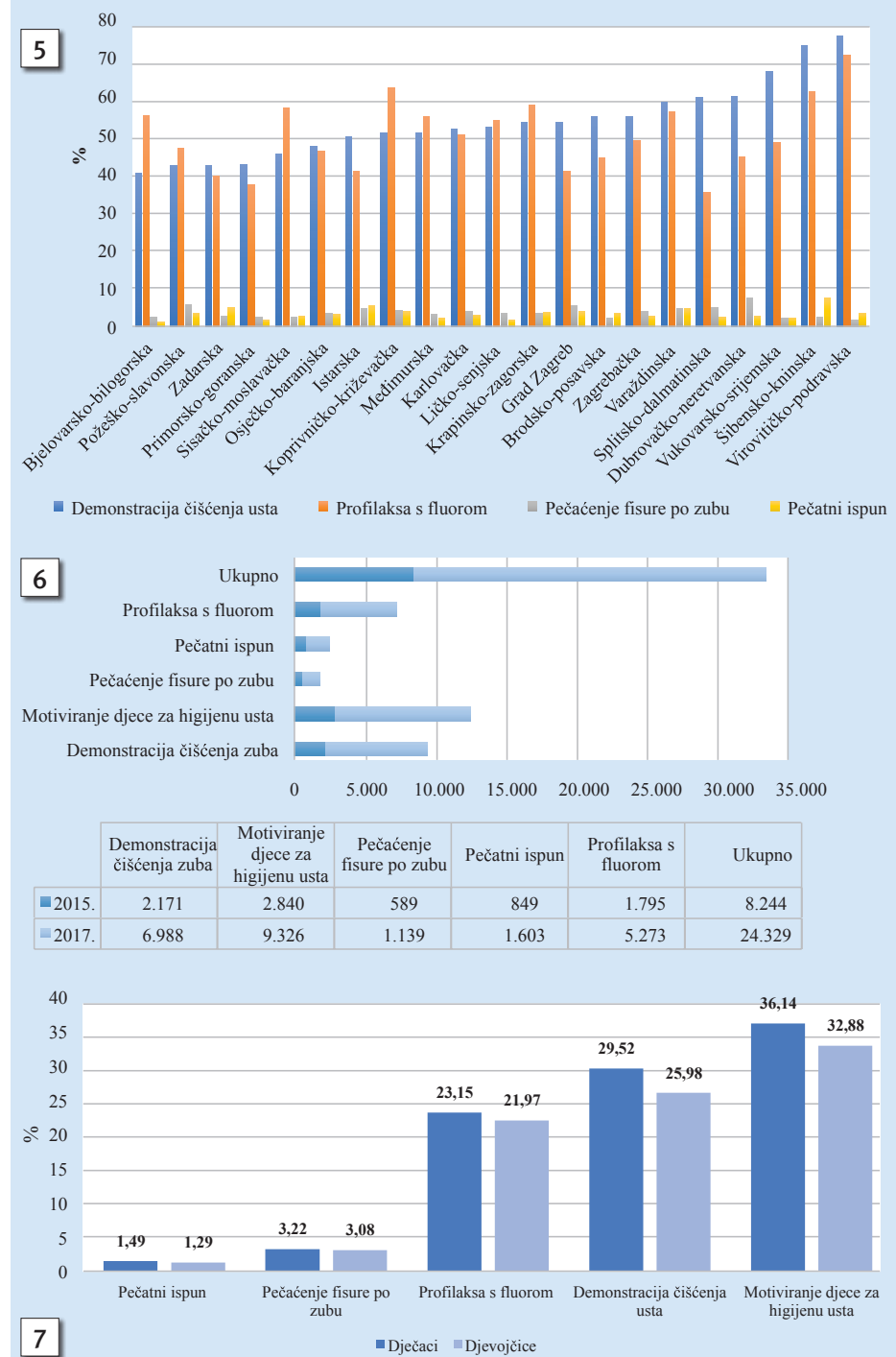

Figure 2 Trends in numbers of diagnostic-therapeutic procedures (CEZIH)

Slika 2. Prikaz kretanja broja dijagnostičko-terapijskih postupaka (CEZIH)

Figure 3 Examined $6^{\text {th }}$ grade students according to counties

Slika 3. Udio pregledanih učenika 6. razreda prema županijama

Figure 4 Preventive procedures for $6^{\text {th }}$ grade students according to sex (Dental Passport Form)

Slika 4. Preventivni postupci kod učenika 6. razreda prema spolu (obrazac Zubna putovnica)

Figure 5 Preventive procedures for $6^{\text {th }}$ grade students in counties (Dental Passport Form)

Slika 5. Prikaz preventivnih postupaka po županijama kod učenika 6. razreda (obrazac Zubna putovnica)

Figure 6 Preventive procedures for $6^{\text {th }}$ grade students in 2015 vs in 2017 (CEZIH)

Slika 6. Broj preventivnih postupaka 2015. vs. 2017. kod učenika 6. razreda (CEZIH)

Figure 7 Preventive procedures in preschool children according to sex at enrolment into $1^{\text {st }}$ grade of elementary school (Dental Passport Form)

Slika 7. Preventivni postupci kod predškolske djece prema spolu pri upisu u 1. razred osnovne škole (obrazac Zubna putovnica) 
prove oral health in children through the Dental Passport program, Croatia begins not only with the revitalization of dental health care in schoolchildren but also in oral health education. Oral health education in an educational setting combined with professional dental preventive care has been shown to produce effective results in reducing dental caries in children. Teaching children how to practice good oral hygiene, with demonstration of brushing techniques and exercises can, except in clinical practice, be performed in schools and it may include daily supervised toothbrushing with fluoride toothpaste. According to the Curriculum for Health Education for Elementary and Secondary Schools within the module "Living Healthy in the Republic of Croatia", nurses from school medicine teams educate children in the first grades of elementary school about proper tooth brushing (19). In the school year 2018/2019, Republic of Croatia launched a pilot project and developed the National Standards for Supervised Toothbrushing in Kindergardens and Primary Schools (20). The results of the Dental Passport program reveal sustainable implementation of dental examinations and preventive procedures in schoolchildren, as school is a right place to carry out population-based prevention programs and public health interventions in health education. The monitoring and creation of databases of oral health indicators through the Dental Passport program and the CEZIH is oriented towards development of consistent national oral health and caries databases. Upon the realization, further activities will be planned. Other important factors in further implementation are greater motivation of dental care providers and the motivation of parents and patients to become more actively involved in the Dental Passport program.

\section{Conclusion}

Good organization of work in school medicine provides the basis for the implementation of dental programs involving school children. The results of the Dental Passport program acknowledge sustainable implementation of dental examinations and preventive procedures in schoolchildren, but there is a need to include preschool children in regular dental check-ups through the Dental Passport program when enrolling in nursery and to implement other prevention measures that include regular oral hygiene, fluoride prophylaxis, proper nutrition and health education in order to decrease the prevalence of caries in children.

\section{Conflict of interest}

None declared bu provođenja preventivnih mjera radi poboljšanja oralnoga zdravlja djece, programom Zubna putovnica, Hrvatska počinje ne samo s revitalizacijom dentalne zdravstvene zaštite kod školske djece, nego i s edukacijom o oralnom zdravlju. Pokazalo se da edukacija o oralnom zdravlju u obrazovnom okružju, u kombinaciji s profesionalnom dentalnom preventivnom skrbi, daje učinkovite rezultate u smanjenju karijesa u trajnoj denticiji kod djece. Edukacija djece o provedbi oralne higijene te demonstracija tehnike i vježbanja četkanja, osim u kliničkoj praksi, može se provoditi u školi te može uključivati svakodnevno nadzirano četkanje zuba s fluoridiranom zubnom pastom. Prema Nastavnom planu i programu zdravstvenog odgoja za osnovne i srednje škole unutar modula Živjeti zdravo u Republici Hrvatskoj, medicinske sestre iz timova školske medicine obavljaju edukaciju djece u prvim razredima osnovne škole o temi pravilnoga pranja zuba (19). U školskoj godini 2018./2019., Republika Hrvatska je počela s pilot-projektom i postavila nacionalne standarde za nadzirano četkanje zuba u vrtićima i školama (20). Rezultati programa Zubna putovnica pokazuju održivu provedbu dentalnih pregleda i preventivnih postupaka kod školske djece, jer je škola pogodno mjesto za provedbu populacijskih preventivnih programa te javnozdravstvenih intervencija u zdravstvenoj edukaciji. Praćenje i stvaranje baze podataka zdravstvenih pokazatelja o oralnome zdravlju na temelju programa $Z u b$ na putovnica i CEZIH, usmjereno je na razvoj konzistentnih nacionalnih baza podataka o oralnom zdravlju i karijesu, a prema njegovu uspostavljanju i planiranju daljnjih aktivnosti. Ostale važne odrednice u daljnjoj provedbi su veća motiviranost pružatelja dentalne zdravstvene zaštite te motiviranost roditelja i pacijenata za aktivnije uključivanje u program Zubna putovnica.

\section{Zaključak}

Dobra organizacija rada u školskoj medicini pruža osnovu za provedbu dentalnih preventivnih programa koji uključuju školsku djecu. Rezultati programa Zubna putovnica pokazuju održivu provedbu dentalnih pregleda i preventivnih postupaka kod školske djece. No postoji potreba za uključivanjem predškolske djece u redovite preglede pri upisu u dječji vrtić kroz program Zubna putovnica i provođenje drugih preventivnih mjera koji uključuju redovitu oralnu higijenu, pravilnu prehranu i zdravstveni odgoj kako bi se smanjila učestalost karijesa kod djece.

\section{Sukob interesa}

Autori nisu bili u sukobu interesa. 
Sažetak

Cilj: Potreba za poboljšanjem oralnog zdravlja u Republici Hrvatskoj temeljila se na zdravstvenim pokazateljima i lošem stanju oralnog zdravlja te je rezultirala provedbom mjera za poboljšanje korištenja dentalne zdravstvene zaštite školske djece na temelju nacionalnog programa Zubna putovnica s kojim se počelo u školskoj godini 2017./2018. Svrha ovog rada bila je predstaviti sadržaj i rezultate provedbe programa te ih analizirati s naglaskom na održivost i obuhvatnost programa te provedbu preventivnih aktivnosti, odnosno postupaka. Materijal i metode: Podatci su prikupljeni iz ispunjenih obrazaca Zubna putovnica od rujna 2017. do kolovoza 2018. godine. Pregledi i dijagnostičko-terapijski postupci (DTP) bilježili su se u sklopu Centralnoga zdravstvenog informacijskog sustava Republike Hrvatske. Rezultati: U školskoj godini 2017./2018. doktora dentalne medicine posjetilo je 24.729 učenika 6. razreda, s odazivom od $68 \%$ za Republiku Hrvatsku. Prema podatcima CEZIH-a u razdoblju od 1. rujna do 31. prosinca 2017. godine kod djece u dobi od 12 godina zabilježeno je povećanje broja prvih pregleda i dijagnostičko-terapijskih postupaka u odnosu prema istom razdoblju 2015. Najrjeđe zabilježeni preventivni postupci kod predškolske djece i učenika 6. razreda bili su pečaćenje fisura po zubu i pečatni ispuni, a demonstracija čišćenja usta i motiviranje djece na higijenu usta bili su najčešći. Zaključak: Dobra organizacija rada u djelatnosti školske medicine daje osnovu za provedbu dentalnih programa u koje se uključuje školsku djecu, ali su također veća motiviranost pružatelja dentalne zdravstvene zaštite u provedbi preventivnih postupaka te motiviranost roditelja i pacijenata za aktivnije uključivanje u program Zubna putovnica, važne odrednice u daljnjoj provedbi i poboljšanju dentalnog zdravlja djece.
Zaprimljen: 17. veljače 2020 . Prihvaćen: 7. svibnja 2020.

Adresa za dopisivanje Ivana Pavić Šimetin Hrvatski zavod za javno zdravstvo ivana.pavic@hzjz.hr

Ključne riječi preventivni stomatološki program, zubna putovnica, preventivni postupci, školska djeca

\section{References}

1. Hrvatski zdravstveni pokazatelji. Zagreb (Hrvatska): Ministarstvo zdravstva i socijalne skrbi Republike Hrvatske, Hrvatski zavod za javno zdravstvo; 2008.

2. Petersen PE, Lennon MA. Effective use of fluorides for the prevention of dental caries in the 21st century: the WHO approach. Community Dent Oral Epidemiol. 2004 Oct;32(5):319-21.

3. Radić M, Benjak T, Dečković-Vukres V, Rotim Z, Filipović-Zore I. Prikaz kretanja KEP indeksa u Hrvatskoj i Europi. Acta Stomatol Croat. 2015 Dec;49(4):275-84.

4. Radić Vuleta M, Pavić Šimetin I, Jurić H, Jurišić Kvesić A, Malenica A. Zubna putovnica- Jačanje preventivne dentalne zdravstvene zaštite djece. In: Mravak-Stipetić M, Sertić J, Jurišić Kvesić A - editors. Opće zdravlje kroz oralno zdravlje - multidisciplinarni pristup. Zagreb: Naklada Hrvatska komora dentalne medicine; 2019. p.4.

5. MeSH Browser [database on the Internet]. Platform for better oral health in Europe. The State of Oral Health in Europe; 2012 [cited 2019 May 28] The State of Oral Health in Europe Report; [about 68 screen]. Available from: http://www.oralhealthplatform.eu/ our-work/the-state-of-oral-health-in-europe/

6. Petersen PE, Torres AM. Preventive oral health care and health promotion provided for children and adolescents by the Municipal Dental Health Service in Denmark, Int J Paediatr Dent. 1999 Jun;9(2):81-91.

7. MeSH Browser [database on the Internet]. Narodne novine. Zagreb: Službeni list Republike Hrvatske; 2009. [cited 2019 July 3] Plan i program mjera zdravstvene zaštite iz obaveznog zdravstvenog osiguranja NN126/2009); [about 2 screen]. Available from: https://narodne-novine.nn.hr/clanci/sluzbeni/2006_11_126_2779.html

8. MeSH Browser [database on the Internet]. Available from: https://www.limesurvey.org/

9. MeSH Browser [database on the Internet]. World Health Organisation. Geneva: What is a Health Promoting School? [cited 2019 May 29] Overview; [about 1 screen]. Available from: https:// www.who.int/health-promoting-schools/overview/en/

10. MeSH Browser [database on the Internet]. World Health Organisation [Internet]. Geneva: Oral Health. [cited 2019 May 29] Important target groups; [about 1 screen]. Available from: https:// www.who.int/oral_health/action/groups/en/
11. Bundy DAP, Schultz L, Sarr B, Banham L, Colenso P, Drake L. The School as a Platform for Addressing Health in Middle Childhood and Adolescence In: Bundy DAP, Silva Nd, Horton S - editors. Child and Adolescent Health and Development. Vol.8. 3rd ed. Washington (DC): The International Bank for Reconstruction and Development / The World Bank; 2017. p. 269-85.

12. Nguyen TM, Hsueh YS, Morgan MV, Mariño RJ, Koshy S. Economic Evaluation of a Pilot School-Based Dental Checkup Program. JDR Clin Trans Res. 2017 Jul;2(3):214-222.

13. Praveen G, Anjum MS, Reddy PP, Monica M, Rao KY, Begum MZ. Effectiveness of school dental screening on stimulating dental attendance rates in Vikarabad town: A randomized controlled trial. J Indian Assoc Public Health Dent. 2014; 12(2): 70-73.

14. Donaldson M, Kinirons M. Effectiveness of the school dental screening programme in stimulating dental attendance for children in need of treatment in Northern Ireland. Community Dent Oral Epidemiol. 2001 Apr;29(2):143-9.

15. Bourgeois DM, Phantumvanit P, Llodra JC, Horn V, Carlile M, Eisel $J$ L. Rationale for the prevention of oral diseases in primary health care: an international collaborative study in oral health education. Int Dent J. 2014 Oct;64 Suppl 2:1-11.

16. Guidelines on the use of fluoride in children: an EAPD policy document. Eur Arch Paediatr Dent. 2009 Sep;10(3):129-35.

17. Kühnisch J, Ekstrand K. R,. Pretty I, Twetman S, Van Loveren C, Gizani S, Spyridonos Loizidou M. Best clinical practice guidance for management of early caries lesions in children and young adults: an EAPD policy document. Eur Arch Paediatr Dent. 2016 Feb;17(1):3-12.

18. Hausen H, Seppa L, Poutanen R, Niinimaa A, Lahti S, Kärkkäinen S, Pietilä I. Noninvasive control of dental caries in children with active initial lesions. A randomized clinical trial. Caries Res. 2007;41(5):384-91.

19. MeSH Browser [database on the Internet]. Agencija za odgoj i obrazovanje. Zagreb: Nastavni plan i program zdravstvenog odgoja za osnovne i srednje škole; 2013. [cited 30 September 2019]; [about 58 screen]. Available from: https://www.azoo.hr/images/ zdravstveni/zdravstveni_nastavni_plan_i_program.pdf

20. MeSH Browser [database on the Internet]. Hrvatski zavod za javno zdravstvo. Zagreb: Nacionalni standardi za program nadziranog četkanja zubi u vrtićima i škoalma;2019. [cited 2020 May 5]; [about 16 screen] Avalaible from: https://www.hzjz.hr/wpcontent/uploads/2020/02/Nacionalni-standardi_nadzirano\%C4\%8Detkanje_SVE.pdf 